\title{
A Comparative Study on the Physicochemical Parameters of Milk of Camel, Cow and Goat in Somali Regional State, Ethiopia
}

\author{
Legesse $\mathbf{A}^{1^{*}}$, Adamu $\mathrm{F}^{2}$, Alamirew $\mathrm{K}^{2}$ and Feyera $\mathrm{T}^{3}$ \\ ${ }^{1}$ Department of Chemistry, College of Natural and Computational Science, Ambo University, Ethiopia \\ ${ }^{2}$ College of Natural and Computational Science, Jigjiga University, Ethiopia \\ ${ }^{3}$ Department of Biomedical Sciences, College of Veterinary Medicine, Ethiopia
}

*Corresponding author: Abi Legesse, Department of Chemistry, College of Natural and Computational Science, Ambo University, Ethiopia, Tel: +251 112362006 ; Email: abi.legesse@yahoo.com

Received date: September 25, 2017; Accepted date: October 03, 2017; Published date: October 06, 2017

Copyright: (c) 2017 Legesse A, et al. This is an open-access article distributed under the terms of the Creative Commons Attribution License, which permits unrestricted use, distribution, and reproduction in any medium, provided the original author and source are credited.

\begin{abstract}
This research was carried out to investigate key physicochemical parameters of milk samples collected from camel, cow and goat in Jigjiga district, Eastern Ethiopia. Sixty fresh milk samples were collected purposively from camels, cows and goats (twenty samples from each species) and analyzed. The results revealed that, cow milk had $6.30 \pm 0.15 \mathrm{pH}, 0.29 \pm 0.04 \%$ titratable acidity, $14.6 \pm 0.60 \%$ total solid, $0.75 \pm 0.07 \%$ ash, $3.54 \pm 0.12 \%$ protein, $5.54 \pm 0.65 \%$ fat and $1.06 \pm 0.03$ specific gravity. Camel milk had $6.13 \pm 0.11 \mathrm{pH}, 0.36 \pm 0.01 \%$ titratable acid, 13.65 $\pm 1.39 \%$ total solid, $0.73 \pm 0.03 \%$ ash, $3.15 \pm 0.15 \%$ protein, $3.93 \pm 0.15 \%$ fat, and $1.03 \pm 0.00$ specific gravity. Results for goat milk was also recorded as $6.38 \pm 0.08 \mathrm{pH}, 0.33 \pm 0.03 \%$ titratable acidity, $14.25 \pm 1.16 \%$ total solid, $0.73 \pm 0.07 \%$ ash, $4.62 \pm 0.56 \%$ protein, $6.79 \pm 0.38 \%$ fat and $1.04 \pm 0.00$ specific gravity. It can be concluded that goat milk had higher protein and fat content than cow and camel milk.
\end{abstract}

Keywords: Camel milk; Cow milk; Goat milk; Jigjiga; Physicochemical parameters

\section{Introduction}

Ethiopia is a country with largest livestock Population in Africa, having different agro ecological conditions including arid and semiarid areas [1,2]. In Fafan Zone of Somali Regional State of Ethiopia including Jigjiga district, pastoralism, agro-pastoralism and sedentary production systems comprise $34.1 \%, 56.8 \%$ and $9.1 \%$ respectively [3]. According to a census conducted by the Central Statistical Agency of Ethiopia [1], the camel, cattle and goat population of Jigjiga district was estimated to be 85000,439000 and 548000 respectively. In the area, there is large milk production from cows, camels and goats, and milk and milk products are important for family consumption and as a source of income through sale of milk products [4].

The quality of raw milk is a term with a very broad meaning. It encompasses such milk characteristics as chemical composition, physical properties, microbiological and cytological quality, sensory properties, technological suitability and nutritive value [5]. Physicochemical analysis is important tool to monitor the quality of dairy products. Milk is an important source of all basic nutrients for mammals. Milk from various mammals are used for producing different dairy products including milk cream, butter, yogurt, ghee, sour milk, etc. Consumers always demands nutritionally enriched milk and dairy products [6]. Fresh milk considered as a complete diet because it contains the essential nutrients as lactose, fat, protein, mineral and vitamins in balanced ratio rather than the other foods [7].

Milk plays a tremendous role in building a healthy society and can be used as vehicle for rural development, employment and slowing down the migration of the rural population [8]. Several studies have reported the presence of the essential components in various animal milks [9]. Milk and milk products are known by its most diversified natural foodstuffs in terms of composition which contains more than twenty different trace elements including copper, zinc, manganese and iron [10]. These trace elements are cofactors in many enzymes and play an important role in the physiological functions of human and animal body. Deficiency of these metals causes disturbances and pathological conditions [11].

Milk and dairy products are part of a healthy diet which, besides cow's milk, sheep's, goats and buffalo's milk are involved [12]. Milk is a complex mixture of fats, proteins, carbohydrates, minerals, vitamins and other minor constituents dispersed or dissolved in water [13]. Milk is an important part of the human diet and the nutritional significance of milk is apparent from the fact that daily consumption of a quart (1.14 liters) of milk furnishes approximately all the daily requirements from fat, calcium, phosphorus, riboflavin, one half of the protein, one third of vitamin $\mathrm{A}$, ascorbic acid, thiamine and one fourth of calories needed daily by an average individual [14].

Cow's milk has long been considered a highly nutritious and valuable human food and is consumed by millions daily in variety of products [15].

Goat has been referred as the "poor man's cow" due to his great contribution to the health and nutrition of the landless and rural poor [16]. Goat milk differs from cow or human milk in having better digestibility, alkalinity and buffering capacity [17].

Camel milk is an important component of human diet in many parts of the world. It considered as an important source of protein for the people living in the arid lands of the world. Camel's milk is characterized with the high content of potassium, magnesium, iron, copper, manganese, sodium and with the lower content of lactose than cow's milk $[18,19]$. Historically, camel's milk has been used for a 
number of medical problems [20], as it has anti-cancer [21], hypoallergic [22] and anti-diabetic [23] properties.

The low quantity of $\beta$-casein and the lack of $\beta$-lactoglobulin are linked to the hypo-allergic effect of camel milk. Other components such as lactoferrin, immunoglobulins, lysozyme and vitamin $\mathrm{C}$ were reported to play a central part in the determination of these properties $[24,25]$.

Camel milk has been consumed for centuries by nomadic peoples for its nutritional value and medicinal properties. Currently, pasteurized camel milk is produced and sold only in a few countries including Saudi Arabia, United Arab Emirates, Kazakhstan, Mauritania and Algeria [26,27].

According to Food and Agriculture Organization of the United Nations (FAO) statistics, there are about 19 million camels in the world, of which 15 million are found in Africa and 4 million in Asia. Approximately 15 million dromedaries, representing two-thirds of the world camel population, are living in the arid areas of Africa, particularly in Northeast Africa (Somalia, Sudan, Ethiopia, and Kenya) [28-30].

Milk is a complex colloidal dispersion containing fat globule, casein micelle and whey proteins in an aqueous solution of lactose, minerals and a few other minor compounds. Its physical properties are affected by several factors including the composition and processing of milk. Measurement of physiochemical properties of milk is used to determine the concentration of milk component and to evaluate the quality of milk products.

The acidity is usually expressed as $\mathrm{pH}$. The $\mathrm{pH}$ of milk is more dependent on temperature than that of buffers, such as phosphate; since milk is a complex buffer system and variation in temperature cause many changes. Differences in $\mathrm{pH}$ and buffering between individual lots of fresh milk reflect compositional variation [31]. The density and specific gravity of milk depend on composition and temperature. Other factors, such as stage of lactation and nutritional status affect density only in as far as they affect composition. The specific gravity of milk decreases slightly with the increasing temperature; partly because of the effect of temperature on milk fat but also because the contraction of the other solids that occurs on mixing with water decreases slightly.

The aim of present study was to assess and compare the physicochemical parameters of milk samples collected from camel, cow and goat of Jigjiga, Eastern Ethiopia.

\section{Materials and Methods}

\section{Description of the study area}

This study was carried out in Jigjiga district, Somali Regional state of Ethiopia. Jigjiga is the capital town of Somali Regional State. It is located at $628 \mathrm{~km}$ to the east of Addis Ababa at $9^{\circ} 20^{\prime}$ north latitude and $42^{\circ} 47^{\prime}$ east longitude. The mean minimum and maximum temperature in the area is $20^{\circ} \mathrm{C}$ and $30^{\circ} \mathrm{C}$, respectively [32]. The average elevation in this district is $1803 \mathrm{~m}$ above sea level, and the average annual rainfall range from $300 \mathrm{~mm}$ to $500 \mathrm{~mm}$ [33].

\section{Milk samples collection and handling}

Sixty fresh milk samples were collected directly from the udder of lactating camels, cows and goats (twenty milk samples from each species) early in the morning using sterile sampling bottles in ice-box, from Jigjiga district, Eastern Ethiopia. The district was considered purposively for its high camel, cow and goat resources and accessibility and logistic purpose. Six Kebeles (the smallest local administrative units) were selected from the district based on the same criteria and willingness of the households to take part in the study. The collected and labeled milk samples were transported to the laboratory of Chemistry Department, Jigjiga University within 4 hours for analysis.

\section{Physicochemical analysis}

The $\mathrm{pH}$ was measured using a digital $\mathrm{pH}$-meter (Model 885, Max electronics, India) calibrated with $\mathrm{pH} 4$ and 7 buffers. Titratable acidity was measured by titrimetric method as described by Bekele. Specific gravity was determined using pycnometer as described by Bekele. The total solids content in milk was determined according to the method of $[34,35]$. Ash content was determined by gravimetric method using a muffle furnace (Model ELF11/14, $1100^{\circ} \mathrm{C}$, Keison, UK) at $550^{\circ} \mathrm{C}$ as described by AOAC. Fat content was determined using Gerber method according to AOAC. Protein content was determined by Kjeldahl method as described by Davide.

\section{Statistical analysis}

The data were statistically analyzed using the statistical program (SPSS program, Statistical Package for Social Sciences version 20). The significant differences between means were calculated by a one-way analysis of variance (ANOVA) using Duncan's multiple-range test at $\mathrm{P}<0.05$.

\section{Results and Discussion}

\section{$\mathrm{pH}$}

$\mathrm{pH}$ of the milk samples collected from different species, namely cow, camel and goat, was determined at the time (early in the morning) and site of sampling. The $\mathrm{pH}$ values of milk samples of those species are given in Table 1 . The result showed that, the $\mathrm{pH}$ value of cow, camel and goat milk was in a range of 5.69-6.70, 5.70-6.49 and 6.18-6.70, respectively. The $\mathrm{pH}$ values of milk samples collected from cow, camel and goat were non-significantly $(\mathrm{p}>0.05)$ different from each other. The $\mathrm{pH}$ values of cow and goat milk were similar with findings of [36-38]. $\mathrm{pH}$ values in camel milk was in agreement with the results reported by Faten and Alajtal. The $\mathrm{pH}$ values of cow, camel and goat milk was lower than the results reported by Faten, which were 6.6, 6.5 and 6.6 , respectively.

\section{Specific gravity}

The specific gravity was in a range of $1.00-1.33 \%$ in cow milk, $1.03 \%$ in camel milk and $1.03-1.04 \%$ in goat milk (Table 1). The specific gravity of cow milk was similar with that of camel and goat milk. The specific gravity of camel milk was also similar with goat milk. There was non-significant $(p>0.05)$ difference between cow, camel and goat milk [39-41]. The specific gravity of milk in cow and goat was in agreement with results reported by Asif and Tilahun. The specific gravity of milk in camel was similar with result reported by Asif et al.

The amount of the studied parameters in the present work was in consonance with reports by some authors and also there were considerable variations when compared to the values reported by others from different parts of the world. This discrepancy may be 
Page 3 of 5

ascribed to such factors as lactation stage [42], feeding, breed, milking frequency, milking system and age of the animal [43].

\section{Titratable acidity}

The values of titratable acidity of milk samples collected from cow, camel and goat and are given in Table 1. It was observed from results that the values of titratable acidity were in the range of $0.12-0.20 \%$ in cow milk, $0.13-0.25 \%$ in camel milk and $0.14-0.22 \%$ in goat milk. Difference between the values of titratable acidity of cow, camel and goat milk was non-significant $(\mathrm{p}>0.05)$. The values titratable acidity of cow milk was in line with that reported by Sumaira et al.

\begin{tabular}{|l|l|l|l|l|}
\hline \multicolumn{2}{|l|}{ Source of milk } & $\begin{array}{l}\text { \%Titratable } \\
\text { Acidity }\end{array}$ & $\begin{array}{l}\text { Specific } \\
\text { Gravity }\end{array}$ & pH \\
\hline \multirow{4}{*}{ Cow } & Maximum & 0.2 & 1.33 & 6.7 \\
\cline { 2 - 5 } & Minimum & 0.12 & 1 & 5.69 \\
\cline { 2 - 5 } & Mean \pm SEM & $0.16 \pm 0.04$ & $1.06 \pm 0.03$ & $6.30 \pm 0.15$ \\
\hline \multirow{4}{*}{ Camel } & Maximum & 0.25 & 1.03 & 6.49 \\
\cline { 2 - 5 } & Minimum & 0.13 & 1.03 & 5.7 \\
\cline { 2 - 5 } & Mean \pm SEM & $0.19 \pm 0.01$ & $1.03 \pm 0.00$ & $6.13 \pm 0.11$ \\
\hline \multirow{4}{*}{ Goat } & Maximum & 0.22 & 1.04 & 6.7 \\
\cline { 2 - 5 } & Minimum & 0.14 & 1.03 & 6.18 \\
\cline { 2 - 5 } & Mean \pm SEM & $0.18 \pm 0.03$ & $1.04 \pm 0.00$ & $6.38 \pm 0.08$ \\
\hline
\end{tabular}

Table 1: Physical properties of various milk samples. The values are Mean \pm SEM; SEM=Standard error of mean.

\section{Total solid content}

The concentration of total solids in milk samples collected from cow, camel and goat is given in Table 2. These results illustrated that the concentration of total solids was in a range of $12.11-16.80 \%$ in cow milk, $10.23-19.40 \%$ in camel milk and $8.17-17.75 \%$ in goat milk. From this result, the amount of total solid in milk samples collected from cow and goat was almost similar. The total solid content of milk sample collected from camel was slightly less than that of milks of cow and goat. Statistical analysis showed non-significant $(p>0.05)$ difference between the concentration of total solids in cow, camel and goat milk. The amount of total solid in camel milk was similar to that reported by Omer. This value was higher than the work reported by Kanwal, it is lower than the results reported by Edwards. The values of total solid of milk samples collected from cow and goat was higher than the values reported by Kholif et al.

\section{Ash content}

Ash content in milk samples collected from cow, camel and goat is given in Table 2. The results of this study revealed that the ash content was in the range of $0.4-1.00 \%$ in cow milk, $0.56-0.80 \%$ in camel milk and $0.66-0.99 \%$ in goat milk. The ash content of the milk samples collected from the three species was similar. There was nonsignificance ( $p>0.05)$ difference between the amount of ash content of milk samples collected from cow, camel and goat. The ash content of milk samples collected from cow, camel and goat were in agreement with the result reported by Kanwal and Sabahelkhier. The ash content of cow milk was higher than the result reported by Kholif and Davide.

\begin{tabular}{|c|c|c|c|c|c|}
\hline \multicolumn{2}{|c|}{ Source of milk } & $\begin{array}{l}\text { \%Total } \\
\text { Solid }\end{array}$ & $\%$ Ash & $\%$ Protein & $\%$ Fat \\
\hline \multirow{3}{*}{ Cow } & Maximum & 16.8 & 1 & 4 & 8.6 \\
\hline & Minimum & 12.11 & 0.4 & 3 & 4.4 \\
\hline & $\begin{array}{l}\text { Mean } \quad \pm \\
\text { SEM }\end{array}$ & $14.60 \pm 0.60$ & $0.75 \pm 0.07$ & $3.54 \pm 0.12$ & $5.54 \pm 0.65 a$ \\
\hline \multirow{3}{*}{ Camel } & Maximum & 19.4 & 0.8 & 3.88 & 4.3 \\
\hline & Minimum & 10.23 & 0.56 & 2.76 & 3.1 \\
\hline & $\begin{array}{ll}\text { Mean } & \pm \\
\text { SEM } & \end{array}$ & $13.65 \pm 1.40$ & $0.73 \pm 0.03$ & $3.15 \pm 0.15$ & $3.93 \pm 0.15$ \\
\hline \multirow{3}{*}{ Goat } & Maximum & 17.75 & 0.99 & 6 & 8.5 \\
\hline & Minimum & 8.17 & 0.6 & 2.05 & 5.8 \\
\hline & $\begin{array}{ll}\text { Mean } & \pm \\
\text { SEM } & \end{array}$ & $14.25 \pm 1.16$ & $0.73 \pm 0.07$ & $\begin{array}{ll}4.62 & \pm \\
0.56 a & \end{array}$ & $6.79 \pm 0.38 b$ \\
\hline
\end{tabular}

Table 2: Chemical components of various milk samples. The values are Mean \pm SEM; SEM=Standard error of mean; superscripts indicate significance when compared with the value in camel $(a=p<0.05$; $\mathrm{b}=\mathrm{p}<0.01)$.

\section{Protein}

Protein content in milk samples collected from cow, camel and goat is given in Table 2. According to these results protein content was in range of $3.00-4.00 \%$ in cow milk, $2.76-3.88 \%$ in camel milk and $2.05-6.00 \%$ in goat milk. The amount of protein content in cow and camel milk was almost similar with non-significance $(p>0.05)$ difference. The amount of protein in goat milk was higher than the milk of two species. There was non-significance difference $(p>0.05)$ between the amount of protein in cow and goat milk. The amount of protein in goat milk had significance difference $(p<0.05)$ when compared to camel milk. The Protein content of cow milk was similar with result reported by Davide and Kanwal. The amount of protein in camel milk was in agreement with that reported by Enb. Protein content in goat milk was higher than that reported by Kholif et al.

\section{Fat}

Fat content in milk samples collected from cow, camel and goat is given in Table 2. Results illustrated that fat content of $4.40-8.60 \%$ in cow milk, $3.10-4.30 \%$ in camel milk and $5.80-8.50 \%$ in goat milk [44]. From this result, the amount of fat in cow milk was slightly less than goat milk with non-significance ( $p>0.05)$ level. The fat content of cow milk was significantly $(\mathrm{p}<0.05)$ higher than camel milk. The values of fat content in goat milk was higher than camel milk at highly significant $(p<0.001)$ level. The amount of fat in camel milk was similar with findings reported by Kanwal and Enb.

\section{Conclusion}

From the tested parameters, the $\mathrm{pH}$, titratable acidity, ash content and specific gravity was almost similar in the milk samples collected from cow, camel and goat. Protein and fat contents were higher in goat 
milk than cow and camel milk. Total solids, fat and protein were lower in camel milk compared to cow and goat milk.

\section{Compliance with Ethical Standards}

\section{Conflict of interest}

The authors declare that they have no competing interests.

\section{Ethical approval}

This article does not contain any studies with human participants or animals performed by any of the authors.

\section{Acknowledgement}

The authors would like to thank Jigiga University Directorate of Research, Publication and Technology Transfer for funding this research

\section{References}

1. CSA (2013) Agricultural Sample Survey, 2012/13 (2005 E.C.) Report on Livestock and livestock characteristics (Private peasant holdings). Statistical Bulletin 570, Federal Democratic Republic of Ethiopia, Addis Ababa.

2. Tilahun H, Schmidt E (2012) Spatial Analysis of Livestock Production Patterns in Ethiopia. ESSP II Working Paper 44. International Food Policy Research Institute/Ethiopia Strategy Support Program II, Addis Ababa, Ethiopia.

3. Belaynesh D (2006) Floristic Composition and Diversity of the Vegetation, Soil Seed Bank Flora and Condition of the Rangelands of the Jigjiga Zone, Somali Regional State, Ethiopia. MSc Hesis, School of Graduate Studies, Alemaya University, Ethiopia pp. 125.

4. Field Surveys conducted by SCUK/DPPB. Food Security Monitoring and Early Warning Programme (2004) Somali Regional State, Ethiopia: Livelihood Zone.

5. Mansour AIA, El-Loly MM, Ahmed RO (2012) A Preliminary Detection of Physical and Chemical Properties, Inhibitory Substances and Preservatives in Raw Milk. Internet J Food Saf 114: 93-103.

6. Kamao M, Tsugawa N, Suhara Y, Okano T (2007) Journal of Health Science 53: 257-262.

7. Hossain MB, Dev SR (2013) Physiochemical Characteristics of Various Raw Milk Samples in a Selected Dairy Plant of Bangladesh. Int J Engin Appl Sci 1: 2305-8269.

8. Sarwar M, Khan MA, Mahr-Un-Nisa ZI (2002) Dairy industry in Pakistan: A Scenario. Int J Agric Biol 4: 420-428.

9. Kholif AM, Abo El-Nor SAH, Abou-Arab AAK, El-Alamy HA (1994) Effeect of spraying diazinon to control the external parasites on the productive performance of dairy animals. I. Yield and composition of buffaloes and Friesian cow's milks. Egyptian Journal of Dairy Science 22: 145-154.

10. Imran M, Khan H, Hassan SS, Khan R (2008) Physicochemical characteristics of various milk samples available in Pakistan. J Zhejiang Univ Sci B 9: 546-551.

11. Schuhmacher M, Borques AM, Domingo LJ, Carbella J (1991) Dietary intake of lead and cadmium from foods in Tarragona Province, Spain. Bulletin of Environmental Contamination and Toxicology 46: 320- 328.

12. Hinrichs J (2004) Mediterranean milk and milk products: Review. Eur J Nutr 43 Suppl 1: 12-17.

13. Harding F (1999) Milk Quality. Chapman and Hall Food Science Book, Aspen Publishers, Inc. Gaithersburg, Maryland, Aspan.

14. Bilal MQ, Ahmad A (2004) Dairy Hygiene and Disease Prevention. Pakistan Vet J :25.
15. Heeschen WH (1994) Introduction. In: Monograph on the significance of pathogenic microorganisms in raw milk. International Dairy Federation, Brussels pp. 8-11.

16. Dresch J (1988) A plea for the goat. Production- Pastorale-et-Societe OAE, 1982. 10: 81-83.

17. Park YW (1994) Hypo-allergenic and therapeutic significance of goat milk. Small Rumin Res 14: 151-161.

18. Gorban AMS, Izzeldin OM (1997) Mineral content of camel milk and colostrum. J Dairy Res 64: 471-474.

19. Hashim IB (2002) Acceptance of camel milk among elementary school students in Al Ain city, Emir. J Agric Sci 14: 54-59.

20. Omer RH, Eltinay AH (2009) Changes in chemical composition of camel's raw milk during Storage. Pakistan J Nutr 8: 607-610.

21. Magjeed NA (2005) Corrective effect of milk camel on some cancer biomarkers in blood of rats intoxicated with aflatoxin B1. J Saudi Chem Society 9: 253-263.

22. Shabo Y, Barzel R, Margoulis M, Yagil R (2005) Camel milk for food allergies in children. Immunology and Allergy 7: 796-798.

23. Agrawal PP, Swami SC, Beniwal R, Kochar DK, Sahani MS, et al. (2003) Effect of camel milk on glycemic control, risk factors and diabetes quality of life in type-1 diabetes: a randomized prospective controlled study. J Camel Practice \& Res 10: 45-50.

24. Elagamy E, Ruppanner R, Ismail A, Champagne C, Assaf R (1996) 3urification and characterization of lactoferrin, lactoperoxidase, lysozyme and immunoglobulins from camel's milk. International Dairy Journal 6: 129-145.

25. Konuspayeva G, Faye B, Loiseau G, and Levieux D (2007) Lactoferrin and Immunoglobulin Contents in Camel's Milk (Camelus bactrianus, Camelus dromedarius, and Hybrids) from Kazakhstan. Journal of Dairy Science 90: 38-46.

26. Dell'Orto V, Cattaneo D, Beretta E, Baldi A, Savoini (2001) Effects of trace element supplementation on milk yield and composition in camels. Inter Dairy J 10: 873-879.

27. Lorenzena PC, Wernery R, Johnson B, Joseb S, Wernery U (2011) Evaluation of indigenous enzyme activities in raw and pasteurized camel milk. Small Rumt Res 97: 79-82.

28. El-Agamy EI, Elsayed I, Mohsen N, Sherif M, Shamsiab A, et al. (2009) Are camel milk proteins convenient to the nutrition of cow milk allergic children? Small Ruminant Res 82: 1-6.

29. Al-Haj OAH, Al-Kanhal A (2010) Compositional, technological and nutritional aspects of dromedary camel milk. Inter Dairy J 20: 811-821.

30. Farah Z (2011) Camel Milk. In: Encyclopedia of Dairy Sciences. 2nd edn. pp: 512-517.

31. Qin W, Dan W, Bin D, Zaijun L, Yanqiang H (2006) Journal of Food Composition and Analysis 19: 76-82.

32. NMSA (National Meteorological Services Agency) (2004) Annual Climatic Bulletin. Ministry of Water Resources, Addis Ababa, Ethiopia, p: 16.

33. Bekele T (2001) Studies on Cephalopina titillator, the case of 'Senegal' in camels (Camelus dromedarius) in semi-arid areas of Somali state, Ethiopia. Tropical Animal Health and Production 33: 489-500.

34. AOAC (Association of Official Analytical Chemists) (2000). Official Methods of Analysis International. 17th Edn. Association of Official Analytical Chemists, Washington. DC.

35. Davide CL (1977) Laboratory guide in dairy chemistry practicals. FAO Regional Dairy Development Centre for Asia and the Pacific. Dairy Training and Research Institute, Univ. Philippines, Los Banos, Laguna.

36. Asif M, Sumaira U (2010) A Comparative Study on the Physicochemical Parameters of Milk Samples Collected from Buffalo, Cow, Goat and Sheep of Gujrat, Pakistan. Pak J Nutr 9: 1192-1197.

37. Kanwal R, Ahmed T, Mirza B (2004) Comparative analysis of quality of milk collected from buffalo, cow, goat and sheep of Rawalpindi/ Islamabad region in Pakistan. Asian Plant Sci 3: 300-305. 
Citation: Legesse A, Adamu F, Alamirew K, Feyera T (2017) A Comparative Study on the Physicochemical Parameters of Milk of Camel, Cow and Goat in Somali Regional State, Ethiopia. Chem Sci J 8: 171. doi:10.4172/2150-3494.1000171

Page 5 of 5

38. Enb A, Donia AMA, Abd-Rabou NS, Abou- Arab AAK, El-Senaity MH (2009) Chemical composition of raw milk and heavy metals behavior during processing of milk products. Global Vet 3: 268-275.

39. Sabahelkhier MK, Faten MM, Omer FI (2012) Comparative Determination of Biochemical Constituents between Animals (Goat Sheep, Cow and Camel) Milk with Human Milk. Res J Recent Sci 1 : 69-71.

40. Elbagermi MA, Alajtal AI, Edwards HGM (2014) A Comparative Study on the Physicochemical Parameters and Trace Elements in Raw Milk Samples Collected from Misurata- Libya. SOP transactions on analytical chemistry 1: 15-23.

41. Shamsia SM (2009) Nutritional and therapeutic properties of camel and Human milks. Int J Genet Mol Biol 1: 052-058.
42. Bhosale SS, Kahate PA, Kamble K, Thakare VM, Gubbawar SG (2009) Effect of lactation on physicochemical properties of local goat milk. Vet World 2: 17-19.

43. Bakht BK, Arshad I (2001) Production and composition of camel milk. Pak 1 Agri Sci 38: 3-4.

44. Ahmed MI, El Zubeir IE (2007) The compositional quality of raw milk produced by some dairy cow farms in Khartoum State, Sudan. Research Journal of Agriculture and Biological Sciences 3: 902-906. 